\title{
Understandings of Impoliteness in the Greek Context
}

\author{
Angeliki Tzanne and Maria Sifianou \\ Department of English Language and Literature \\ National and Kapodistrian University of Athens, \\ Panepistimioupoli Zographou, 15784 Athens, Greece
}

\begin{abstract}
Interest in non-academic ways of understanding of im/politeness has so far been evident primarily in analyses of the sequential development of real-life interactions. However, understandings of im/politeness can be found in other sources such as related articles in on-line newspapers and their ensuing comments. The main aim of this paper is to contribute to this rather neglected area in im/politeness research, thus placing emphasis on the underexplored societal rather than individual level of im/politeness. The data to be investigated comes from two on-line articles and the comments they received. The articles appeared in a popular Greek free press on-line newspaper, LIFO, in 2014 and 2017 and were written by the same journalist. Both articles and ensuing comments express lay understandings of impoliteness and are discussed in the paper in terms of van Dijk's $(1998,2006 \mathrm{a}, \mathrm{b})$ ideological discourse analysis and 'ideological square' that revolves around positive self-presentation and negative other-presentation. In exploring understandings of impoliteness in this context, we identified two emerging social identities, those of 'polite' and 'impolite citizen', dynamically co-constructed as binary opposites by the journalist and posters involved. Despite the fact that on-line newspaper articles and their accompanying comments reflect stereotypical thinking, they also depict pervasive views and are worth exploring because they concern the societal level of im/politeness.
\end{abstract}

Keywords: Impoliteness, lay conceptualisations, ideological discourse analysis, identity construction, on-line newspaper articles, Greek

\section{For citation:}

Tzanne, Angeliki \& Sifianou, Maria (2019). Understandings of impoliteness in the Greek context. Russian Journal of Linguistics, 23 (4), 1014 -1038. doi: 10.22363/2687-0088-2019-23-4-1014-1038.

\section{Понимание невежливости в греческом контексте}

\author{
Ангелики Цанне и Мария Сифиану \\ Афинский национальный университет им. Каподистрии, Греция \\ Panepistimioupoli Zographou, 15784 Athens, Greece
}

\begin{abstract}
Аннотация
Анализ понимания (не)вежливости на бытовом уровне обычно проводится на основе исследований реального взаимодействия. Однако для данных исследований можно использовать и другие источники, например, соответствующие статьи в онлайн газетах и последующие комментарии.
\end{abstract}


Основная цель данной статьи - внести вклад в эту мало изученную область, сделав акцент на социальном, а не индивидуальном уровне (не)вежливости. Материалом для исследования послужили две онлайн-статьи и комментарии к ним. Статьи были написаны одним и тем же журналистом и опубликованы в популярной греческой онлайн-газете LIFO в 2014 и 2017 годах. Обе статьи и последующие комментарии выражают бытовое понимание невежливости и обсуждаются нами с точки зрения идеологического дискурс-анализа ван Дейка $(1998,2006 a, b)$ и «идеологического квадрата», который вращается вокруг позитивной презентации себя и негативной презентации другого. Изучая понимание невежливости в этом контексте, мы определили две бинарно противоположные социальные идентичности - вежливого и невежливого гражданина, совместно сконструированные журналистом и авторами комментариев. Несмотря на то, что статьи в онлайн-газетах и сопровождающие их комментарии отражают стереотипное мышление, они представляют широко распространенные взгляды и заслуживают изучения, поскольку затрагивают социальный уровень (не)вежливости.

Ключевые слова: невежливость, концептуализация, идеологический дискурс-анализ, конструирование идентичности, статьи в онлайн-газетах, греческий язык

\section{Для цитирования:}

Tzanne, Angeliki \& Sifianou, Maria (2019). Understandings of impoliteness in the Greek context. Russian Journal of Linguistics, 23 (4), 1014 -1038. doi: 10.22363/2687-0088-2019-23-4-1014-1038.

\section{Introduction}

Discursive approaches to im/politeness have suggested a distinction between lay understandings of politeness or 'first order' politeness and politeness as a theoretical construct or 'second order' politeness. Despite the fact that over the years it has become clear that such a straightforward dichotomy is difficult to maintain, it has triggered academic interest in non-academic understandings of politeness and impoliteness which, as has been argued, should receive more attention in im/politeness research. Among various sources, such understandings can be found in articles and ensuing comments in on-line newspapers dealing explicitly with issues of im/politeness.

Despite the fact that the views expressed may reflect stereotypical and ideological thinking (Brown 2015, Culpeper 2011, Mills 2009, 2017), they are worth exploring because they concern the rather underexplored societal rather than the individual level of politeness. It is precisely to this neglected area in im/politeness research that our paper aims to contribute.

The data that will serve as the source of our discussion comes from two on-line articles written by the same journalist and dealing specifically with the issue of impoliteness, and the comments following these publications. In exploring lay understandings of impoliteness in this on-line context, we will be mainly concerned with the social group identities that the journalist and commenters appear to co-construct. From our analysis, impoliteness emerges from the system of social norms and values of politeness presumably shared by a group of citizens the identity of which is constructed explicitly in the discourse of both articles and ensuing comments. The group identity of 'impolite citizen' is presented as the binary opposite of another group identity, that of 'polite citizen', the identity of which is primarily constructed through implication and inference in the data examined. 
The paper is structured as follows: We will start with a brief consideration of what lay conceptualisations of im/politeness involve and then add some key features of on-line newspaper comments and identity construction. We will then proceed with the data analysis and the presentation and discussion of findings.

\section{Lay conceptualisations of im/politeness}

As mentioned earlier, politeness researchers (e.g., Eelen 2001, Watts 1989, 2003, Watts et al. 1992) have drawn a well-known but also contested distinction between 'first order' (or P1) politeness and 'second order' (or P2) politeness, the former referring to 'folk' or 'lay' interpretations/understandings of im/politeness and the latter to a theoretical construct in a sociolinguistic theory (Watts 2003: 4). Although it has by now become evident that such a dichotomy can no longer be sustained (see, e.g., Haugh 2012, Haugh and Culpeper 2018, Kádár and Haugh 2013: 84, 104, Mills 2003: 8, Terkourafi 2011: 180), it has drawn scholarly attention to non-academic understandings of im/politeness which, as several studies argue, should receive more attention in im/politeness research (see, e.g., Culpeper 2011, Haugh 2012, Locher and Watts 2005: 16, Mills 2003, Watts 2003).

This distinction was the incentive for the emergence of research which analysed in detail examples from real-life interactions focusing on the assessments made by participants in the unfolding of these interactions. Despite their offering valuable insights into understandings of im/politeness, such assessments tend to emerge at textual moments of disagreement/conflict, are tied to a specific time and place and mostly reflect the heterogeneity of understandings (Davies et al. 2013: 275). Moreover, as Kádár and Haugh (2013: 199) and Locher (2013: 203) rightly point out, evaluations of im/politeness may not necessarily surface in interaction. Notwithstanding shortcomings, such interactional data is an appealing source for exploring understandings of im/politeness but one can also find understandings of $\mathrm{im} /$ politeness in on-line articles and ensuing comments dealing explicitly with issues of $\mathrm{im} /$ politeness. In the same way that non-linguists frequently talk about language issues, they also talk about $\mathrm{im} /$ politeness and what constitutes in/appropriate behaviour, talk which "comes under the umbrella of metapragmatics" which, as Kádár and Haugh (2013: 181) argue, is "of particular importance to the study of politeness" because it offers a broader perspective than interactional data. As Kádár and Haugh (2013: 202) note, a useful window into metadiscourses on im/politeness comes from analyses of comments or debates that arise in the media. Such sources have received some attention for instance in the work of Haugh (2010), O'Driscoll (2013) and Terkourafi et al. (2018) who analyse in-depth perceptions of the offensiveness of e-mails and tweets which received wide public attention. In such cases, judgements relate to evaluations of language as polite, impolite or offensive. Closer to our approach, in a very recent article, Locher and Luginbühl (2019) explore the competing understandings of im/politeness discussed in on-line commentaries by German and Swiss posters. In other words, in both cases the topic of the discussion is $\mathrm{im} /$ politeness per se rather than some other issue which developed into a conflictual heated discussion. 
Thus, even though there is a plethora of publications on on-line reader comments and impoliteness, what, to the best of our knowledge, has not received much attention are metadiscourses that deal explicitly with the concept of im/politeness in both the articles and the comments and more specifically with the lack of politeness shown to (usually unknown) others in public encounters. Such impoliteness metapragmatic comments are "articulations of prescriptive rules concerning behaviours in the light of particular social norms" (Culpeper 2011: 73) "or more broadly ideologies" (Haugh 2007: 307). Mills (2009, 2017 and elsewhere) maintains that statements about $\mathrm{im} /$ politeness at a cultural level tend to be ideological, conservative and based on stereotypes. Despite such valid concerns, such data is invaluable and worth exploring because even though lay descriptions may be inaccurate and based on stereotypes and prejudices, they embody pervasive beliefs and attitudes (Pinto 2011: 218, drawing on Preston 2005). For their part, Niedzielski and Preston (2003: 323) advocate that "the nonspecialist views of topics which touch the lives of all citizens are worth knowing for their bearing on public life". Drawing on Jaworski et al. (2004: 3), Culpeper (2011: 73) maintains that the role of these metalinguistic representations is twofold: "on the one hand they are data for understandings, and on the other hand they become structured understandings. In other words, they both reflect thought and influence it". We would like to add here that these understandings are worth exploring since they concern the societal level which has been rather neglected in im/politeness research. As is well-known, core concepts in impoliteness research are those of 'face' and 'face-threatening' acts/behaviour and their impact on individuals. At the societal level, individuals are not concerned with each other's face protection so much as they most probably do not know each other, nor do they aim at constructing or establishing a relationship. As Davies et al. (2013: 271) contend "local negotiations of politeness and the identities they construct are important, but these negotiations are always played out against a backdrop of societal and cultural beliefs". Impoliteness at the societal level has to do more with the breach of social norms and conventions. Such norms constitute "authoritative standards of behaviour, and entail positive or negative evaluations of behaviour as being consistent or otherwise with those standards" (Culpeper 2011: 36). This difference is evidenced in that comments relating to impoliteness at the societal level are usually accompanied by other-condemning emotions, such as anger and contempt rather than self-conscious emotions such as embarrassment and shame which would be the result of violations of face wants (Culpeper 2011: 62). Lakoff (2005), Grainger and Mills (2016) and Mills (2017) contend that the term 'in/civility' could be used to describe im/politeness phenomena at the social level, since the term 'im/politeness' is better suited to describe such phenomena at the individual level. This is an interesting suggestion that has not been taken up in the relevant literature and, in our view, merits further exploration (but see Sifianou 2019). Such concerns can also be found in the in/civility literature expressed in the distinction between 'proximate' and 'diffuse' civility. Proximate civility is often equated with 'politeness' or its absence in interaction and covers both verbal and non-verbal communication. Diffuse civility involves a broader spectrum of behaviours which impact on others even without their presence (Fyfe et al. 2006: 855). Related is Boyd's (2006: 864) distinction between 'formal' and 'substantive' 
civility; the former is limited to manners, politeness, courtesies and other interactional formalities, whereas the latter "denotes a sense of standing or membership in the political community with its attendant rights and responsibility".

As it transpires from the above, exploring and encompassing (though not reifying) various lay understandings/theorisations of im/politeness in our quests is a promising perspective that should be considered. Therefore, in this paper, we will focus on lay understandings of impoliteness in Greek found in two on-line articles and ensuing comments referring to this topic and hope to show the significance of such understandings for the construction and maintenance of social group identities vis-à-vis im/politeness.

\section{On-line newspaper communication and impoliteness}

In their effort to encourage community dialogue, on-line newspapers offer public space for readers to voice their opinions through the comments they can post at the end of the articles written by journalists. Sometimes, these comments are civil, but research on on-line communication has raised serious concerns about the incivility in most such contexts. As Barnes (2018: viii) notes, even though the internet has brought new means of communication, "it is often the darker side of communication-incivility, abuse and harassment - that is synonymous with this new frontier" (see also Reader 2012, Upadhyay 2010).

This presumed dominance of impoliteness in the media is mostly attributed to the anonymity and the subsequent deindividuation afforded by on-line platforms. Dynel (2015: 338) contends that Internet users' anonymity infuses "a sense of impunity and lack of inhibitions" and these facilitate the occurrence of impoliteness (see also Bou-Franch and Garcés-Conejos Blitvich 2014, Hardaker 2010, Hardaker and McGlashan 2016, Lorenzo-Dus et al. 2011, Reader 2012, Thurlow et al. 2004). Research has indeed shown that incivility is more common in contexts where users can retain their anonymity (see, e.g., Oz et al. 2017, Rowe 2015, Santana 2014). However, most researchers agree that "there are multiple factors that influence online commenting culture" (Barnes 2018:114) such as the varying affordances of the platforms and the fact that they attract different types of audiences rather than anonymity alone. In addition, they contend that comments regarding morally loaded, sensitive topics (e.g., same-sex marriage) were more impolite than comments to less sensitive topics (e.g., technology). Thus the topic of the discussion appears to be a significant variable in exploring the quality of interaction (Berg 2016).

As can be gleaned from the above, some scholars argue that anonymity exacerbates aggressiveness and even hostility whereas others contend that anonymity has benefits as it encourages the expression of unconventional views and thus promotes a pluralistic dialogue, free speech and broader participation (see, e.g., Papacharissi 2004, Reader 2012, Scott, 2004). What is more relevant for us here is that anonymity may also lead to an increase in the salience of social identity since "deindividuated contexts are conducive to individuals constructing themselves mostly as members of relevant social categories, i.e. to social or collective identity construction" (Lorenzo-Dus et al. 2011: 2581). As we shall show below, posters construct their identities in relation to likeminded others and in opposition to others who are not members of this in-group. 
As previously mentioned, impoliteness has been found to proliferate especially when contentious topics are involved (see, e.g., Bou-Franch and Garcés-Conejos Blitvich 2014, Mutz and Reeves 2005, Oz et al. 2017, Santana 2014). Im/politeness itself can be such a topic, not only because people have different views as to what it is and how it is manifested, but also because journalists and alarmists love to draw sweeping overgeneralisations that magnify what is seen as impolite and thus draw attention and instigate comments. Discursive approaches to im/politeness research have emphasised the inherent variability in evaluations of behaviour as polite, impolite and so on while at the same time stressing that these individual variabilities can be recognised in juxtaposition to more general societal norms. Yet there are contexts such as that examined here where, as we will see later, impressive homogeneity and unanimity dominate (cf. Locher and Luginbühl 2019).

\section{Identity construction}

The relationship between language and identity has been of concern to social scientists for years but they mostly viewed identity as based on stable relationships between linguistic and social variables. In recent years, this stability has been challenged not least because of large-scale sociocultural and political changes (see, e.g., Archakis and Tsakona 2012, Archakis and Tzanne 2009, Benwell and Stokoe 2006, Bucholtz and Hall 2003, 2005, Canakis 2007, Garcés-Conejos Blitvich and Sifianou 2017, Joseph 2004, Locher 2008). Researchers have shown how "we build images of ourselves through language, how society moulds us into different categories, and how we negotiate our membership of those categories" (De Fina et al. 2006). Johnstone (2008: 151) sees identity as referring "to the outcome of processes by which people index their similarity to and difference from others, sometimes self-consciously and strategically and sometimes as a matter of habit". In other words, identity work has been seen as both active and passive with the former referring to cases "when individuals are relatively aware of their self-constructions", and the latter to work which "occurs through more routine processes" (Wieland 2010: 507). The breadth and complexity of the relationships between identities and their discursive constructions has led to distinctions such as that between personal and collective or group identity (see, e.g., Hardaker and McGlashan 2016, Joseph 2004, Watson 2008, Wieland 2010), a distinction, however, which is not as clear-cut as it first appears (Joseph 2004: 6). As Joseph (2004: 5) explicates, one's "personal identity is made up in part of the various group identities to which you stake a claim". Moreover, as Garcés-Conejos Blitvich and Sifianou (2017: 247, drawing on Hall and Du Gay 1996 and Mouffe 2005), point out, "identities are the product of difference and exclusion rather than unity, as it is only in relation to the other, to what one is not, that recognition is produced" (see also Joseph 2004: 46). As Bucholtz and Hall (2005: 605) argue "identities emerge only in relation to other identities within the contingent framework of interaction". The concepts of 'identity' and 'identity work' are highly complex and the literature diverse (see, e.g., Howard 2000, Garcés-Conejos Blitvich 2013, Locher 2008, Locher and Bolander 2017) so it is impossible to paint an overall picture (Howard 2000: 387). 
What is more, cyberspace has foregrounded issues of identity construction, making the social construction of identity more visible and in some cases at least more selfconscious (Luzón 2018, Marwick 2013). Given the mostly public nature of interactions, visibility has emerged as a core property of the system reinforcing posters' concern with identity construction, "an ongoing performance of identity" in order to connect with like-minded others (Zappavigna 2012: 38).

In this paper, we approach identity as dynamically co-constructed in social interaction rather than as a permanent and stable feature of individuals, differentiating between explicit and implicit identity construction (Bolander and Locher 2015) and showing that implicitness is often preferred over explicitness.

\section{The data}

As mentioned earlier, the data for this paper comes from two on-line articles and ensuing comments. Both articles appeared in one of the popular Greek free press on-line newspapers, LIFO, and were written by the same journalist. The first,

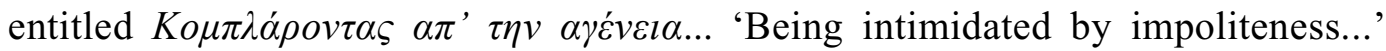
(https://www.lifo.gr/team/apopseis/51270?comments_page=2\&comments_order=

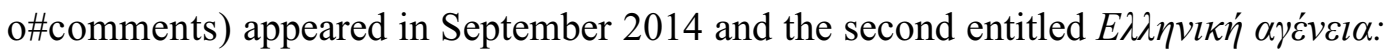

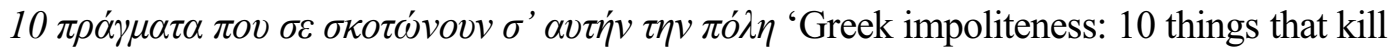
you in this city' (https://www.lifo.gr/articles/health-fitness_articles/158512/ellinikiageneia-10-pragmata-poy-se-skotonoyn-s-aytin-tin-poli) appeared three years later in September 2017. The first article is accompanied by a screenshot, most probably from a Greek film, depicting a young girl with her tongue sticking out in front of two elderly men. The second article is accompanied by a screenshot of the late, Harry Klynn, very popular Greek stand-up comedian and singer. The photo, drawn from the TV series Made in Greece, depicts him performing a very popular obscene gesture. In fact, one poster commented on this photo saying that the article is very good but the photo is even better.

The first of these articles received only 16 comments whereas the second one received 35 comments and was shared 265 times. ${ }^{1}$ In both cases, all posters used nicknames. After downloading the articles and the comments, each post was coded as either an initial post, where the poster addressed the content of the article in a new "thread", or as a reply, where the poster directly addressed a comment from another poster, or another participant. The number of likes/dislikes a comment received was also recorded. All comments, with a couple of exceptions, as we will see below, endorsed the journalist's views and received many more likes than dislikes. We will not provide a detailed account of all of this, but instead restrict ourselves to a very brief overview and concentrate on the practices that relate to the construction of the $\mathrm{im} /$ polite citizen' identity.

1 The numbers were accurate at the time of collecting our data but are slightly different today. There was no mention of shares for the first one. 


\subsection{The first article: "Being intimidated by impoliteness..."}

In the first article (624 words), the journalist starts with two constructed examples through which she attempts to illustrate her general point that by being polite over the phone in an interaction with the public sector she failed to get through to her intended addressee whilst she managed to do so when she called back and sounded rather abrupt and determined. She then says that we all have various problems due to the financial crisis but the main problem is our bad mood which has developed into a tendency to be rude and cheeky both when we speak and when we write. She highlights that the view that you win by being polite and smiling is a joke. The journalist proceeds with a number of examples which indicate our verbal impoliteness such as the absence of greetings and of V-forms (indexing formality and politeness in Greek) to socially distant others. She adds that we draw delight in interrupting others (to say, usually, something stupid) and we feel confident that in order to be heard we have to shout which is evidenced everywhere. We think highly of ourselves and behave like donkeys when in tight corners, according to the author.

\subsection{The second article: "Greek impoliteness: 10 things that kill you in this city"}

The second article is longer (1574 words) and appears to be a kind of "revised and extended version" of the first one. The first article gravitates towards verbal $\mathrm{im} /$ politeness with few mentions of behavioural im/politeness whereas, in the second article, behavioural $\mathrm{im} /$ politeness takes precedence, with verbal im/politeness also being included. By behavioural im/politeness we mean non-linguistic modes of behaving mostly in public places and transport facilities which are deemed im/polite. This second article more clearly involves the societal level, assessing mostly public encounters between strangers in crowded places and the service sector, and embraces issues relating to etiquette, such as table manners. In our view, behavioural im/politeness is a significant aspect of im/politeness that merits our attention, given that existing theories are mostly preoccupied with linguistic behaviour (but see Fukushima and Sifianou 2017, Locher and Luginbühl 2019, Ogiermann and Saloustrou 2019, Sifianou and Tzanne 2010).

In this article, the journalist starts her long preface by saying that Greek people do not admit being extremely impolite perhaps for fear of the attacks that this statement will incite. According to the journalist, Greek people are deeply rude.

Very succinctly put, the things that infuriate the journalist in Athens include behaviour in the street, on pedestrian walkways and at crossings where people push and shove, obstruct others' movement and park in spots reserved for the less able. Similarly inconsiderate is behaviour on public transport where people push to get on, without waiting for others to get off, and reach a vacant seat first. In service encounters people are rude as they do not greet and ignore queues, protocols and rules. People interrupt others to say, usually, something stupid and pretend to be know-alls. They are noisy and speak loudly so they are heard by everybody at the restaurant and in the train compartment. Children are left to scream and shout and when people return home, they turn the television on full volume despite it being quiet hours. In public toilets, 
people litter, don't wash their hands and don't inform those waiting that there is a mess inside. They are inconsiderate with animals leaving dogs unattended, even tied to banging chains. People ignore the dress code and table manners. In case of both faceto-face and on-line disagreement, people will swear. They are indiscreet and will ask the most incredible questions so that they can gossip later but at the same time they are rather cowardly because if queried, they will deny everything or even go on the attack. For some unexplainable reason, people believe that they are better, smarter and more capable than most others. They believe they are never wrong, and if accused of being wrong, they accuse others of being unjust.

We should note here that all the data was and still is publically available so we believe there are no ethical issues in their use (see, e.g., Locher and Bolander 2019, Locher and Luginbühl 2019). However, to ensure anonymity we have removed all names and nicknames from the examples used as illustrations including that of the journalist. We have also retained the grammar and spelling of the original. We also deem significant to note that we do not assume that all citizens of Athens behave in this way or even share the views of the journalist and the posters. We offer our findings as a glimpse into some of the kinds of impoliteness that the journalist and some posters view as worth mentioning and bring them up in their discussion. As Kádár and Haugh (2013: 202) note, the interest in analysing such metadiscourses does not lie on their being objectively true but "on how they are perpetuated as dominant within societies, as well as on how they may be challenged or contested".

\section{Constructing group identities vis-à-vis im/politeness}

As mentioned earlier, views about im/politeness at a societal/cultural level tend to be stereotypical and ideological. According to van Dijk (2006a: 124), "[i]f ideologies are acquired, expressed, enacted and reproduced by discourse, this must happen through a number of discursive structures and strategies". Drawing upon Halliday's (1985) Functional Grammar and van Dijk's (1998, 2006a, b) ideological discourse analysis, in this section, we proceed with an analysis of the discourse of the two articles and the below-the-line comments in order to interpret the lexical and grammatical patterns of the texts in terms of their functions and the identities they help to construct.

Our findings will be discussed in the light of van Dijk's (1998, 2006a, b) 'ideological square' which posits that ideological discourse is polarised and features four strategies that associate all positive meaning with $U s$, the in-group, and all negative meaning with Them/the Other, the out-group. Even though the model was developed to explain anti/racist social ideologies, almost all categories proposed "are rather general resources that groups and their members acquire and use in order to account for and defend their ideas and social practices" (van Dijk 2006b: 739). Applying this model to the analysis of discourse that expresses social values and beliefs relating to $\mathrm{im} / \mathrm{poli}$ teness can further our understanding as to how being verbally aggressive, together with agreeing with, praising and complimenting the Other can become ideologically loaded indexes of identity construction in the case of im/polite citizens.

In the sections that follow, we argue that the discourse used by the journalist and the posters appears to construct explicitly and in detail the values, practices and norms 
that are associated with the identity of 'impolite citizen'. At the same time, it makes some explicit reference to, but mainly provides indications for, the implicit construction of the identity of 'polite citizen', which is generally considered to be the binary opposite of 'impolite citizen'.

\subsection{Constructing the identity of 'impolite citizen'}

Beginning our analysis, the first point to be made is that the topic of both articles, foregrounded and noticeable already from the titles of the articles ("Being intimidated by impoliteness..." and "Greek impoliteness: 10 things that kill you in this city"), is impoliteness/rudeness. The lexical items $\alpha \gamma \varepsilon \dot{\varepsilon} v \varepsilon \alpha$ 'impoliteness' and $\alpha \gamma \varepsilon v \eta$ ' 'impolite' are frequently repeated in both the articles and the comments, as are to a lesser extent

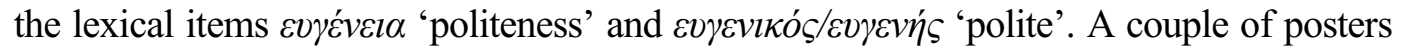
also used the plural form $\varepsilon v \gamma \varepsilon$ vel $\varsigma$ *'politenesses' which is used ironically to indicate surface forms which lack substance. It is through this repetition and the lexical cohesion thus created that the identities of 'impolite' and 'polite citizen' emerge in the texts. Interestingly, the identity of 'impolite citizen' is constructed as a social group identity and the values of the group are outlined through the use of several discursive strategies creating meanings which "are not explicitly expressed, but presupposed to be known, and inferable from general sociocultural knowledge" (van Dijk 2006b: 739).

First of all, the pronoun 'we' is used extensively throughout both articles, culmi-

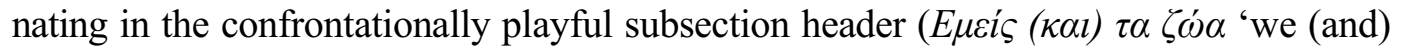
the animals') in the second article. In most occurrences, 'we' is the implied grammatical subject of verbs in the first person plural, while there are also cases where this 'we' is explicitly mentioned and capitalised possibly denoting shouting and anger, as, for in-

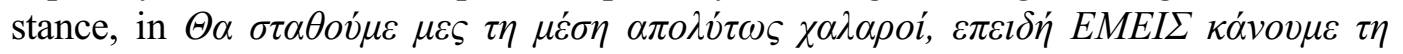
$\beta o ́ \lambda \tau \alpha \mu \alpha \varsigma$ 'We'll stand in the middle [of the road] perfectly relaxed, because WE are out for a walk'. This pronoun is also used by some posters when they provide additional information as to what constitutes typical behaviour of an impolite Greek citizen.

Discussing the ideology of polarised social groups, van Dijk (2006a: 124) presents the pronoun 'we' as a discursive structure "typically used to deictically refer to the ingroup of the current speaker". In this case, 'we' is to be taken as inclusive, referring to a group of people displaying similar verbal and non-verbal behaviours that emanate from shared values. Interpreted in this way, the extensive use of 'we' by the journalist and posters appears to signify their membership in the group of 'impolite citizens'. Before delving into the reason why these posters present themselves as belonging to a group related to impoliteness, we would like to turn our attention to the examination of the behaviours and values that are presented as related to this social group.

In the data, impolite citizens are presented as actors of many action processes that relate semantically to (physical) violence (e.g., $\theta \alpha \sigma \pi \rho \omega ́ \xi \xi o v \mu \varepsilon$ 'we'll push' / $\theta \alpha \pi \alpha \tau \dot{\sigma} \sigma o v \mu \varepsilon$ 'we'll tread'). Moreover, some of these actions are illegal ( $\theta \alpha \pi \varepsilon \rho \alpha ́ \sigma o v \mu \varepsilon \sigma \alpha \nu \beta o \lambda i \delta \varepsilon \varsigma$ $\alpha \pi o ́$ $\tau \eta \Lambda E A$ 'we'll speed down the emergency lane') and generally deviant $(\theta \alpha$ $\lambda \varepsilon \rho \omega ́ \sigma o v \mu \varepsilon$ 'we'll throw litter', $\theta \alpha \pi \alpha \rho \kappa \alpha ́ \rho o v \mu \varepsilon \sigma \tau \eta v \alpha \nu \alpha \pi \eta \rho \iota \kappa \eta ' \theta \varepsilon ́ \sigma \eta$ 'we'll park in the disabled space'). In addition to material actions, impolite citizens are presented to be involved in many verbal processes that are viewed as inconsiderate and socially unac- 


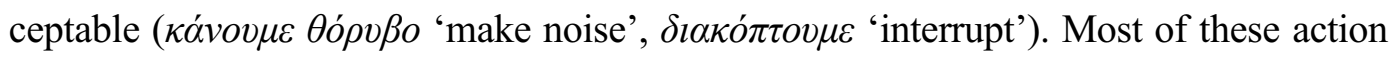
and verbal processes are transactive ones, with the action passing on to some recipient who is in this case, the polite citizen and their surroundings/belongings $(\theta \alpha \alpha \gamma v o \eta$ rov $\mu \varepsilon$

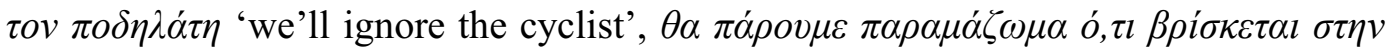
$\alpha \kappa \tau i$ 'v $\alpha \alpha \varsigma$ 'we'll knock down everything around us'). Presenting polite people as the affected participants results in their victimisation which is also found in the recounting of polite people's personal experiences (see section 6.2).

Drawing on Bucholtz and Hall (2005), Locher (2008: 513) states that "agency in identity construction should not be understood as a fully rational and always conscious process since there are undoubtedly aspects that are habitual" (emphasis in the original). We believe that presenting actions such as the above in the simple present tense stresses their habitual nature and implies that these acts constitute persistent behaviour of impolite citizens ( $\varphi \omega v \alpha ́ \zeta o v \mu \varepsilon$ 'we shout'). In addition, in terms of modality, that is the author's attitude towards the truth of their statements, the use of simple present ( $\delta \varepsilon v \chi \alpha \mu o \gamma \varepsilon \lambda \dot{\alpha} \mu \varepsilon$ 'we don't smile') or future tense $(\theta \alpha \alpha \varphi \eta ́ \sigma o v \mu \varepsilon \tau \alpha \pi \alpha l \delta l \alpha$ ' $\mu \alpha \varsigma \alpha \mu o \lambda \eta \tau \dot{\alpha}$ 'we'll let our children loose') aids to present these actions as categorical and general truths (cf. Verschueren 2012: 99), thus presenting journalist and posters as belonging to the group that has the truth (van Dijk 2006a: 125).

That these actions depict general truth is also reinforced by the extensive use of 'we' in the data, the function of which appears to be the "enhancement of persuasion". As Temmerman (2014: 251) argues, with the use of generic 'we', that is, with an indefinite agent, the highest degree of objectivity and generalization is produced, which obscures the subjectivity of the argument. In this way, speakers overshadow their presence and present their argument as a general truth. ${ }^{2}$ In our case, the journalist's and posters' use of inclusive 'we' leaves no room for exceptions. The readers will thus be predisposed to accept these views as being the only correct ones. Such generalisations as the ones discussed above are not uncommon and reflect ideologies about politeness and appropriate civil behaviour (Mills 2017: 52).

Concerning the features and related values of 'impolite citizen', several negatively loaded lexical items are attributed to the group, such as $\theta \rho \alpha \sigma u ́ \varsigma$ 'audacious', $\alpha \delta i \alpha$ ' $\kappa \rho \imath \sigma \varsigma$ 'indiscreet' $\alpha \gamma \rho \alpha \dot{\mu} \mu \alpha \tau o \varsigma$ 'uneducated', $\beta \lambda \alpha \dot{\alpha} \kappa \alpha \varsigma$ 'unintelligent'. One poster in full agreement with the journalist uses a number of these attributes saying that 'modern Greeks are a mixture of uneducated, uncivilised, uncouth, self-centered human beings ${ }_{\text {DIM }}$ who

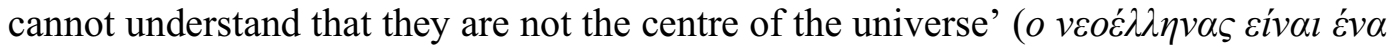

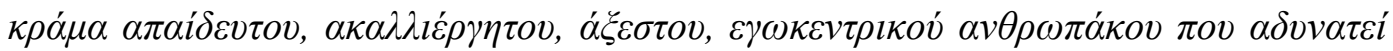

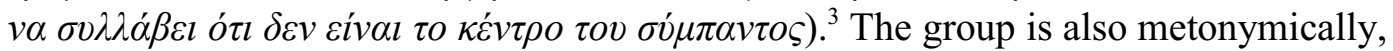
derogatively termed $\varepsilon \lambda \lambda \eta v \alpha ́ \rho \alpha \varsigma$ ' $\mathrm{Greek}_{\mathrm{AUGM}}$ ', while, in a striking overgeneralisation, a commenter attributes modern Greek people the negative characteristics of $\alpha v \dot{\eta} \theta \imath \kappa o l$ 'immoral' and $\pi \alpha v \eta \gamma v ́ \rho t$ 'good-for-nothing'. Finally, through presupposition and impli-

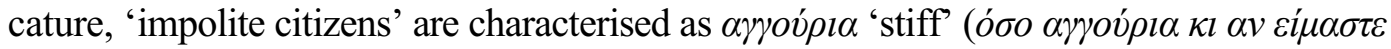

${ }^{2}$ Generalisation is also one of the strategies discussed by van Dijk (2006b: 737) "typically used to formulate prejudices about generalized negative characteristics of immigrants".

3 The diminutive is used derogatively. 
'no matter how stiff we are') and shown to be wrong-doers ( $\alpha \nu \mu \alpha \varsigma v \pi o \delta \varepsilon i \xi o v v \tau o$ $\lambda \dot{\alpha} \theta o \varsigma$ 'if people point out our wrong-doings').

At this point, it is interesting to note that, contrary to our expectations concerning the way in which $U_{s}$ /in-group is presented (van Dijk 1998, 2006a, b), in our data, $U s$ is clearly presented in negative terms. This appears to come into sharp contrast with Eelen's (2001: 39) statement that "people never identify with impoliteness, but always see themselves as generally polite". The question that arises at this point is whether the journalist and participating posters do indeed consider themselves to belong to the group of impolite people outlined in the articles. The response to this question is located in the authors' use of 'we'. As Pavlidou $(2014: 1,2)$ states, "wwe' is imbued with a kind of complexity that goes beyond the usual problems associated with person deixis and reference" and its "referent can only be retrieved on the basis of utterance and discourse context as well as shared knowledge". Evidence from the discourse of both the articles and comments examined confirms the complexity of 'we', as it leads to the conclusion that the journalist's and posters' 'we' is rather speaker-excluding, in the sense that neither the journalist nor the posters seem to position themselves in the group of impolite people they chastise.

In case the people involved did view themselves as belonging to the group of impolite people they described, they would be inflicting serious face damage on themselves and their social identity, since, as our analysis has shown, they strongly disapprove of and criticise harshly the behaviours they present. Aligning with people one severely criticises would go against the fundamental human desire to be evaluated positively by others, what Spencer-Oatey (2002: 540) calls 'quality face'. For his part, van Dijk (2006b: 739) identifies a "positive self-presentation (semantic macrostrategy)" according to which people will generally try to make a good impression or avoid making a bad impression. In addition, if the journalist herself belonged to the impolite out-group, she would probably not have noticed such behaviour and thus would not have written the article. The author becomes aware of the Other's impolite behaviour exactly because she positions herself in a different group of people who assume they are polite and are thus able to observe from a distance, recognise impolite behaviour when they see it and comment on it. On the other hand, the impolite Other her/himself most probably does not realise that $\mathrm{s} /$ he acts in an impolite and uncivil manner. As Smith et al. (2010: 12) note "rudeness comes into existence only when it is detected" and "is almost always a property attributed to others" (Eelen 2001: 39).

Close inspection of the articles and ensuing comments reveals that through the use of specific negative terms to characterise the impolite citizen (e.g., $\varepsilon \xi v \pi v \alpha \dot{\alpha} \kappa \eta \delta \varepsilon \varsigma$ 'know-

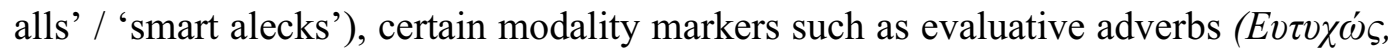

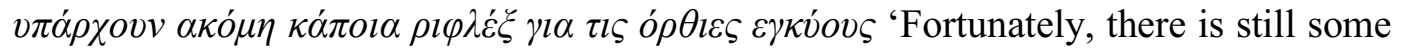
consideration for pregnant women standing'), rhetorical devices such as irony (Kal $\tau l$

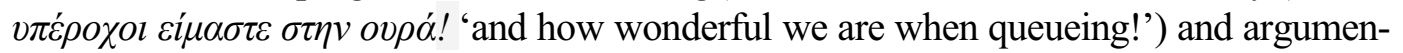
tation (in the second article, the journalist builds an argument justifying the occurrence of impoliteness only to refute it in the next paragraph), both journalist and commenters manage to express their criticism against and disapproval of the identity of 'impolite citizen'. In this way, they obviously dissociate themselves from the group of impolite citi- 
zens they describe and claim membership in the group of polite citizens that is implicitly outlined as the binary opposite (see section 6.2).

It is thus reasonable to argue that through the writers' implicit/covert disapproval and heavy criticism of the practices they describe as being typical of the impolite Greek citizen, 'we' becomes speaker-exclusive. Through this harsh criticism, journalist and commenters reject the identity of 'impolite citizen' and appear to endorse that of 'polite citizen', an identity outlined in broad, general terms, mostly implicitly in relation to the 'impolite citizen' identity. In other words, it appears that through strong criticism and disapproval of others' behaviours, and overall agreement with each other and the journalist, the posters co-construct the identity of the Other as impolite and their own, by extension, as polite. As Alexander (2006: 50) observes, "the civility of the self always articulates itself in language about the incivility of the other".

\subsection{Constructing the identity of 'polite citizen'}

In this section, we present discursive strategies with which the journalist and several commenters construct through some explicit mention, but mostly implicitly, the identity of 'polite citizen'.

First of all, the identity of 'polite citizen' emerges through the recurrent use of the lexical items $\varepsilon v \gamma \varepsilon v \eta ́ \varsigma / \varepsilon v \gamma \varepsilon v \imath \kappa o ́ \varsigma ~ ' p o l i t e '$ and $\varepsilon v \gamma \varepsilon ́ v \varepsilon \imath \alpha$ 'politeness' which outline the main feature of the group members. It is interesting to note that, to the mind of some

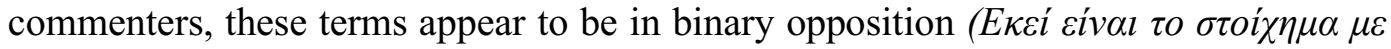

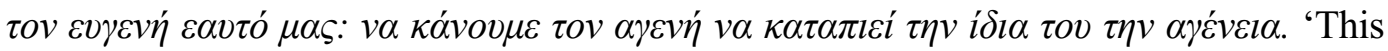
is where the steak with our polite self lies: to make impolite people swallow their own impoliteness'). In this case, 'we' are clearly the polite citizens, while 'they' are the impolite ones. The same binary opposition is implied in the statement of the same commenter, when they say that the only way to win the battle with impoliteness is to deal with it with humour and self-control.

Although the identity of 'polite citizen' is not expanded on or elaborated to the extent that the identity of 'impolite citizen' is, there are additional lexical items which attribute positive features to the group. For instance, a poster characterises their verbal behaviour 'civil', while another states that impolite behaviour in the form of jumping

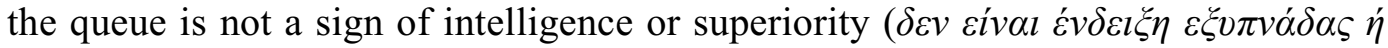

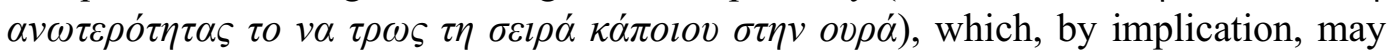
mean that the opposite (respecting the queue) is polite behaviour indeed associated with these positive features.

Intelligence is a feature that is implicitly, rather than explicitly, attributed to the identity of 'polite citizen', confirming Bolander and Locher's (2015: 106) claim in relation to Facebook status updates that "individuals tend to favor implicit means of constructing their identities over explicit ones". At the face of it, posters often attribute to the group of polite citizens the negatively loaded terms $\beta \lambda \alpha \dot{\alpha} \alpha \varsigma / \eta \lambda i \theta l o \varsigma / \chi \alpha \zeta o$ s 'stupid'/ 'idiot'/'dummy', but the rhetorical means they use (e.g., metaphor/comparison $\sigma \alpha v$ $\chi \alpha \zeta o$ $\varsigma / \sigma \alpha v \beta \lambda \alpha \alpha \alpha \varsigma$ 'like an idiot'), together with the use of subjective modality denoting low factuality ( $\mu \varepsilon \theta \varepsilon \omega \rho o v ́ \sigma \alpha \nu \beta \lambda \alpha \dot{\alpha} \alpha$ 'they considered me stupid') show polite citizens to be the intelligent ones by implication. This polarisation of values concerning the two 


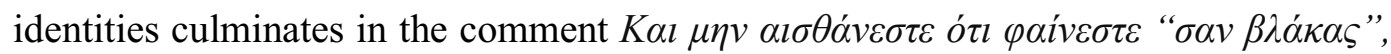

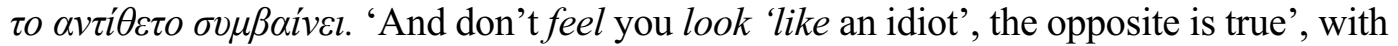
subjective modality and the rhetoric of comparison almost eliminating factuality (you are an idiot). To this should be added the attribute $\gamma v \dot{\gamma} \sigma ı$ or $\eta \lambda i \theta l o r$ 'true idiots' the journalist uses in her second article to refer to the group of impolite citizens.

In discussing politeness within the UK, Mills and Kádár (2011: 30) maintain that there is a clear association between politeness and class-based refinement and education, and it is the middle classes which are often referred to as 'polite society'. This association is also evident in Greek as the word for polite ( $\varepsilon v \gamma \varepsilon v \eta \dot{\zeta} / \varepsilon v \gamma \varepsilon v ı \kappa o ́ \varsigma)$ derives from $\varepsilon v$ 'good' and $\gamma \dot{c}$ 'vos 'origin'/‘descent'. Thus originally the term described someone of good origin, a member of the elite and then by extension one of refined manners who behaves according to societal norms and is ethically, intellectually and esthetically superior (Dictionary of Standard Modern Greek website). The etymology may not be of direct relevance to ordinary Greek speakers but may have reverberations. Thus some posters explicitly state their feeling of superiority towards impolite citizens ( $v \iota \omega ́ \theta \omega$ ó $\iota$ v 'I feel superior') or assume a superior position of expertise and authority (cf. Eller 2017), believing that they can instruct others concerning what politeness means and how it should be practised. In this respect, polite citizens appear as truly knowledgeable, which is the exact opposite of 'know-alls', a negative term attributed to impolite citizens (see section 6.1).

Finally, 'polite citizens' appear to associate themselves with the negative attribute 'weak' both explicitly ( $v \iota \omega \theta \omega \alpha \delta v$ v $\alpha \mu \varsigma^{\prime}$ 'I feel weak') and implicitly by presenting themselves as victims of the impolite Other. A commenter writes $\kappa \alpha ́ \pi \circ \tau \varepsilon \tau o ́ \lambda \mu \eta \sigma \alpha v \alpha$

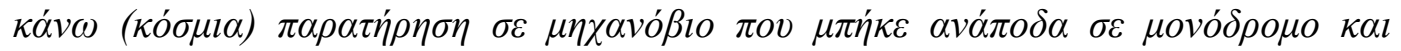

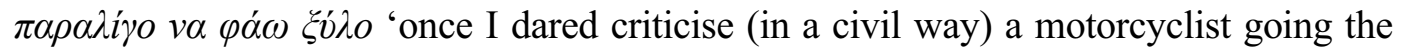
wrong direction in a one-way street and got almost beaten up'. This comment is interesting in that the poster recounts a personal experience to lend support to their views and provide further evidence for the problems discussed (Eller 2017). This 'victimisation' strategy, according to van Dijk (2006b: 739), serves to emphasise the 'bad' nature of the Other, who is, in this case, the impolite citizen. The impolite Other is thus constructed as the agent of aggressive, illegal and socially unacceptable acts and the poster as the polite citizen who was (almost) the recipient of these acts. In this way, the Other strongly comes across as a person who deserves disapproval and criticism because of their impolite, unacceptable behaviour.

Examining the way polite people are presented to react to impoliteness, we observe that, in most cases, they appear as Sayers, that is, animate entities who initiate and become involved in verbal processes which are generally considered relatively harmless

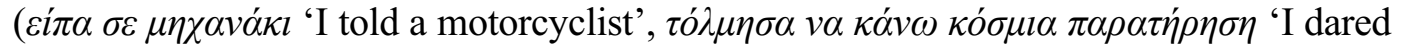

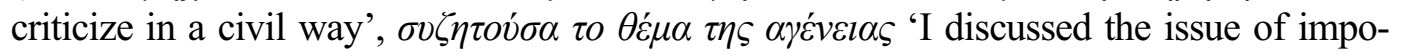
liteness') as compared to action processes, especially violent ones, like the actions of impolite citizens (see section 6.1). In general terms, the impolite, disrespectful and aggressive behaviours delineated in the articles and comments may generate intimidation and cannot be tolerated as the journalist states in the concluding paragraph of her first article. The first poster to comment on this states that when $\mathrm{s} /$ he visits a public service 
or a shop and his/her greeting is not reciprocated, s/he asks an irrelevant, very rude question and thus intimidates the assistant who would like to respond in kind but cannot do so. Another poster agrees with reacting in kind to those who are rude and justifies this by saying that nobody is going to learn and change through your example in this context of anarchy; you will simply be the loser. The commenter mentioned earlier who feels superior to his/her compatriots is also in favour of being rude to those who are

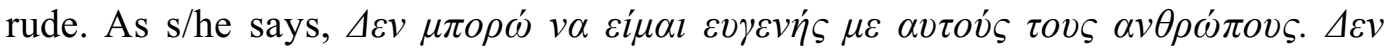

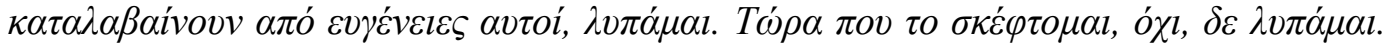
'I can't be polite with these people. They don't understand what politeness is, these people, I'm sorry. Now that I think of it, no I'm not sorry'. Thus rudeness is advocated but it is legitimised as being provoked by the rude Other and it is thus their fault. In other words, it is not Us who are rude, it is the Other's behaviour which needs straightening this way. This is the kind of rudeness that Kienpointner $(1997: 266,2018)$ calls reactive and its function is to restore the balance of power. He (1997: 271) further notes that it is legitimised because it is a reaction rather than an initiating action. The above comments echo theoretical discussions on the social norm of reciprocity which dictates that any prosocial, antisocial, etc. behaviour should be matched (Culpeper 2011: 37, reporting social psychological literature) and is seen as "fundamental to human interpersonal relations" (Ohashi and Chang 2017: 262). As Lodewijkx (2008) explains, the norm of reciprocity "calls for positive reactions to favorable treatment and for negative reactions to unfavorable treatment". Thus, reciprocity has both positive and negative aspects. In Perugini and Gallucci's (2001: 19) words "[r]eciprocity is in fact a powerful mechanism to shape others' actions by delivering rewards and punishment". Posters provide negative evaluations or react in kind when their conventionally polite behaviour is not reciprocated. However, what is emphasised more in the comments is its negative aspect, that is, the necessity for negative reaction to unfavourable treatment. Observing this norm, posters argue that one should be rude to those who are rude, a view that is consistent with findings of research on aggression, namely that verbal insults and taunts are reciprocated (Culpeper 2011: 205).

\subsection{Claiming membership in the group of 'polite citizens'}

Quoting Kristiansen (2003), Georgalou (2017: 12) states that "[i]n using language, we portray ourselves in terms of both linguistic content (what we say/write) and linguistic form (how we say/write it)". In this section, we discuss the ways in which, reacting to the journalist's two articles, posters claim membership in the group of polite citizens. Aligning with this identity through their comments confirms Barnes' (2018: 30) claim that comments "could be viewed as a performance of self, used as a method of not only self-expression, but also identity construction".

Recent research claims that "the sections provided for reader response are certainly not intended as spaces for achieving and displaying consensus and peaceful harmony but rather constitute public arenas where debate is not only accepted but even valued" (Eller 2017: 369). Yet the opposite appears to be true in our data, since the comments we examined displayed admirable consensus and were almost all unanimous in their agreement with, and support of, the journalist's views. Specifically, almost all posters 
fully endorsed the journalist's unflattering views of the citizens she portrays as impolite in her articles (but see Locher and Luginbühl 2019).

Following the journalist's practice, commenters also used the inclusive 'we'

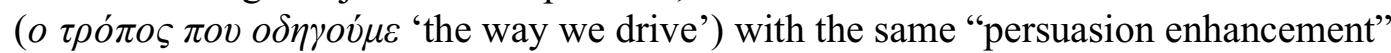
function discussed earlier (section 6.1) and levelled their criticism against the 'impolite citizen', thus implicitly aligning with the identity of 'polite citizen'. Posters not only agreed with the journalist but some added further examples of presumed impoliteness to the journalist's list, such as providing unsolicited advice as to how to raise your child, and the way cafés and restaurants occupy pavement space with tables and chairs, thus obstructing the passage of those who are physically challenged. It is notable that these endorsing posts are the ones which received the most likes. This is not surprising because, as Watts (2003: 5) notes, commentators on and participants in interactions tend to agree far more readily about what is perceived as being impolite rather than polite.

The one poster who expressed an overall different view received more dislikes (121) than likes (54), even though the disagreement was prefaced with a disclaimer

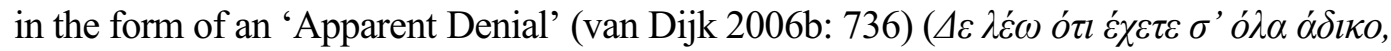

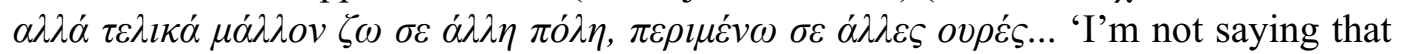
you are wrong in everything, but I must be living in a different city, joining different queues...'). In addition, this was one of the few posts that received a comment directly

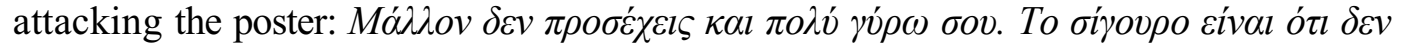

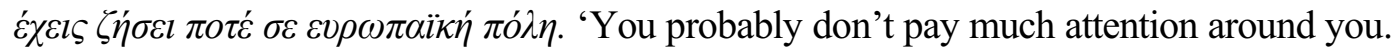
It's certain that you've never lived in another European city'. By accusing the other poster of being out of touch with social reality, s/he challenges his/her objectivity and thus the veracity of his/her views. When faced with an opposing view, people frequently revert to personal attacks, which tend to be seen as more impolite than issue-based attacks (Neurauter-Kessels 2011, Stryker et al. 2016, Upadhyay 2010). The other two posters who expressed disagreement were in overall agreement with the journalist and raised only one issue of contention each. The first argued that Greeks do care about the dress code (the $7^{\text {th }}$ instance of impolite behaviour described in the second article), and the second that $\mathrm{s} / \mathrm{he}$ is indeed superior to most of his/her compatriots (the $10^{\text {th }}$ instance of impolite behaviour in the second article), as s/he does not behave in the impolite ways they do. It thus appears that even though it is true that impoliteness is "conspicuously a subjective and variable notion involving understandings of behaviours in context" (Culpeper 2011: 66), when it comes to metadiscourses at the societal level, unanimity can be found at least in certain contexts.

What is noteworthy is that no poster attempted to chastise either the journalist or any of the commenters for their hyperbole and rather impolite tone (cf. NeurauterKessels 2011). One poster provided a list of suggestions as to what could be done to improve the situation and ended their comment by congratulating the author on the article and on bringing the topic to readers' attention. For another commenter, the only way to achieve an improvement is through personal example, and s/he offered a list of his/her own "polite" behaviours which could function as a blueprint for others. This reflects the view that civility promotes the ideal by example (Sellers, 2003), since direct encounters with a social model appear "to reactivate the common behavioral norm 
of politeness", a kind of behavioural contagion (Moser and Corroyer 2001: 623, see also Culpeper 2011: 204). However, offering one's polite behaviours as examples also implies a certain degree of social and intellectual inferiority of the Other in that it presupposes their ignorance. Two other posters strongly endorsed this tactic, whereas another disagreed, calling this approach passive behaviour which is not going to help anybody change. This is one of the two contested issues between posters, the other being responding rudely to rude behaviours (see section 6.2).

Another poster attributes ignorance to the Other saying that unfortunately this excellent article which describes Greek reality accurately was read by those who did not really need to read it as they know how to behave, whereas it has almost certainly been ignored by people who should read it. This is the kind of awareness that Kádár and Haugh (2013) call 'metapragmatic awareness', that is, lay observers' awareness about the ways in which they interact with others and more specifically 'metadiscursive awareness' referring "to reflexive social discourses on politeness that are constituted (and contested) at a societal or cultural level" (Kádár and Haugh 2013: 269). As the authors (Kádár and Haugh 2013: 41) explain, speakers are consciously aware of the lay concept of politeness but may not be necessarily aware all the time of politeness in practice.

Extensive agreement between posters and journalist is coupled with several

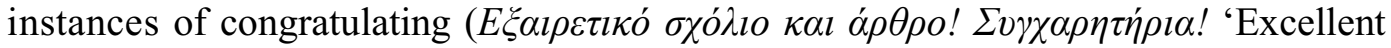
comment and article! Congratulations!'), praising ('АЧОГО post 'IMPECCABLE post!')

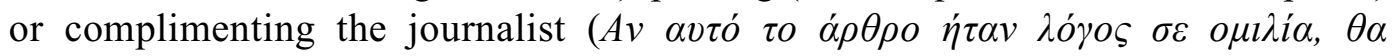

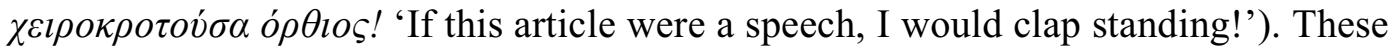
communicative acts create and reinforce solidarity and contribute to the construction of an in-group (see Tzanne 2019) involving both journalist and posters. Using speech acts such as congratulating, complimenting and praising to presuppose 'Our' good things, and interaction strategies such as agreement to imply 'Our' good things (van Dijk 2006a: 126), commenters appear to fully endorse the journalist's views concerning impoliteness and to assume, like her, the identity of 'polite citizen'.

\section{Discussion and concluding remarks}

This study explored views of impoliteness as presented in two on-line newspaper articles and the ensuing comments. Such articles are not uncommon and as Mills (2017: 51) maintains "[n] ewspapers regularly comment on politeness norms and a supposed decline in civility". This supposed decline is neither a new nor a culturallyspecific phenomenon. As Smith et al. (2010: 1) vividly elucidate: "Through the ages and across civilizations there has always been talk of poor public behaviour, of increasingly unruly streets and of the decline and fall of good manners". The authors add further that "[i]t is a current journalistic staple to document troublesome youth, identify emergent forms of disorder from 'road rage' to 'cell phone rage', and to conduct simple experiments or cheap stunts to demonstrate that common courtesies are no longer to be found in the urban jungle".

What is relatively new is that the media and the on-line version of newspapers have helped highlight and spread such views by offering individuals the opportunity 
to express their views and evaluate others' presumed politeness or more frequently impoliteness. Both journalists and posters tend to assume that it is possible to generalise about Greek (or any other for that matter) im/politeness and are mostly in agreement as to what it is and how it should (should not) be practised. This overall agreement is significant in our view because even though there is variability across individuals as to their perceptions of impoliteness (see, e.g., Eelen 2001), there are contexts where concurrence is high. This then affects the way we see the social world around us since such metalinguistic comments, especially when unanimous, influence our understandings, as mentioned earlier. In other words, our evaluations are not based solely on our personal experiences (cf. Eelen 2001: 39).

The views expressed in the two articles are very similar with the interesting difference that the first concentrates mostly on verbal / linguistic impoliteness whereas the second concerns itself mostly with non-verbal behavioural aspects of impoliteness. This is noteworthy in our view because it demonstrates that lay understandings of impoliteness are not confined to language which has been the playground of most politeness research but includes a wide array of non-verbal behaviours (Culpeper 2011, Fukushima and Sifianou 2017, Locher and Luginbühl 2019, Sifianou and Tzanne 2010). Moreover, these metapragmatic comments attest a difference between non-academic and academic views on what impoliteness is and how it is realised.

Some of the issues raised and the examples provided could be accounted for by the impoliteness strategies and their outputs proposed by Culpeper (1996), later modified and expanded (for an overview see Culpeper 2011), especially those relating to verbal behaviour. However, issues such as littering or mistreating animals, and the general disregard and intolerance described by the journalist and the posters do not seem to fit comfortably within existing impoliteness categorisations, unless one sees them as falling under a broad understanding of ignoring or snubbing the other, a strategy which can be highly impolite or uncivil (Mutz 2015: 7). As Lorenzo-Dus et al. (2011) show, lay assessments of impoliteness often relate to norms associated with civility. The relationship between im/politeness and in/civility is an issue that, with the exception of Sifianou (2019) has been mostly neglected in im/politeness research and deserves consideration. These metapragmatic comments attest a further difference between non-academic and current academic views on politeness and impoliteness. Current politeness research (see, e.g., Kienpointner 1997, Mills 2003) rightly argues that politeness and impoliteness cannot be seen as binary opposites. Interestingly, the lay understandings of im/politeness analysed here show that, to the mind of the journalist and posters, politeness and impoliteness do emerge as binary opposites. In this respect, our findings lend support to, and provide evidence for, Eelen's (2001) theoretical claim that popular views on im/politeness stand in binary opposition. From our data, a simple, albeit clear, opposition between politeness and impoliteness seems to emerge which facilitates and leads to the construction of two social group identities, those of impolite and polite citizens.

The analysis of our data shows that evaluations/complaints about impoliteness are intimately related to issues of identity construction. In particular, from the discourse of the articles and the ensuing comments, two social group identities emerge in a relation of polarity and opposition between in-group/Us and out-group/Them, involving polite 
and impolite citizens, respectively. In the data, the identity of the impolite citizen is painted in unmistakably bleak colours, which implicitly creates the exact opposite identity for the polite citizen. Criticising and disapproving of the impolite behaviours they discuss, automatically enables journalist and posters to align with the exact opposite polite behaviours, and, therefore, to ensure their membership in the group of polite citizens.

The two groups appear to be differentiated on the basis of the following features which are indications of the values the groups hold:

(a) power: polite citizens often report feeling weak in their social encounters with impolite citizens, thus showing the latter to have control over their course of action; however, the weakness they report emerges as a subjective feeling and not as factual evidence; moreover, by characterising impolite citizens as really/truly weak, they present their own group as powerful by implication;

(b) knowledge: impolite citizens are presented as know-alls, while the group of polite citizens presents themselves as being truly knowledgeable;

(c) education: impolite people are characterised as uneducated who need tutoring, whereas, by implication, polite people are the exact opposite who can undertake the role of instructor;

(d) civilisation: impolite citizens are characterised as uncivilised, while, by implication, polite citizens are civilised;

(e) intelligence: polarising groups on the basis of (lack of) intelligence is a common practice in discourses expressing ideologies (van Dijk 1998). In our case, the group of impolite citizens seems to fallaciously believe that they are intelligent and consider polite citizens to be stupid; however, the journalist and commenters characterise impolite citizens as 'smart alecks' and 'true idiots', while polite citizens such as themselves are presented as the genuinely clever ones.

Resulting from all the above, polite citizens consider themselves to be in a position superior to that occupied by the impolite ones; after all, when they report to be 'weak' in the presence of impolite citizens, they talk about an impression they have, and not about reality / factuality. Relatedly, they present themselves as intelligent, knowledgeable and educated people who can contribute to the public debate on the significant social issue of im/politeness.

Concerning anonymity and relationships among participants in this on-line context, we should at this point note that the posters who responded to the two articles on $\mathrm{im} /$ politeness are most probably not familiar with one another, nor do they aim at establishing or maintaining a personal relationship. Being on-line and anonymous, they appear keener on co-constructing a favourable in-group identity and secondarily a personal one as a member of a refined and educated group who has in addition a gate-keeping role to play. In this sense, it could be argued that the group of polite citizens here represented mostly by the journalist and commenters have undertaken the task to educate the 'uncivilised' Other, that is, the impolite citizen. They assume they can do this through their words or preferably through their deeds, as one poster says but also through imposing sanctions. By imposing sanctions and treating rudely those they perceive as rude they claim power and affirm their own worth (cf. Smith et al. 2010: 73). 
In conclusion, despite the fact that on-line newspaper articles and ensuing comments reflect stereotypical thinking, they also depict pervasive views and are worth exploring because they concern the underexplored societal rather than the individual level of im/politeness. With our paper, we hope to have contributed to a better understanding of these views and of the social identities they help construct vis-à-vis im/politeness.

\section{(C) Angeliki Tzanne and Maria Sifianou, 2019 (c) creative}

\section{https://creativecommons.org/licenses/by/4.0/}

\section{REFERENCES}

Alexander, Jeffrey C. (2006). The civil sphere. Oxford: Oxford University Press.

Archakis, Argiris \& Villy Tsakona (2012). The narrative construction of identities in critical education. Basingstoke: Palgrave Macmillan.

Archakis, Argiris \& Angeliki Tzanne (2009). Constructing in-group identity through story-telling: evidence from conversational narratives of young people in Greece. In Georgakopoulou, A. \& V. Lytra (eds.) Language, Discourse and Identities: Snapshots from Greek Contexts. Pragmatics Special Issue, 19 (3), 343-362.

Barnes, Renee (2018). Uncovering online commenting culture: Trolls, fanboys and lurkers. Switzerland: Palgrave Macmillan.

Benwell, Bethan \& Elizabeth Stokoe (2006) Discourse and identity. Edinburgh: Edinburgh University Press.

Berg, Janne (2016). The impact of anonymity and issue controversiality on the quality of online discussion. Journal of Information Technology \& Politics, 13 (1), 37-51.

Bolander, Brook \& Miriam A. Locher (2015). "Peter is a dumb nut": Status updates and reactions to them as 'acts of positioning' in Facebook. Pragmatics, 25 (1), 99-122.

Bou-Franch, Patricia \& Pilar Garcés-Conejos Blitvich (2014). Conflict management in massive polylogues: A case study from YouTube. Journal of Pragmatics, 73, 19-36.

Boyd, Richard (2006). The value of civility? Urban Studies, 43 (5/6), 863-878.

Brown, Penelope (2015). Politeness and language. International Encyclopedia of the Social \& Behavioral Sciences (2nd ed.), 18, 326-330. http://dx.doi.org/10.1016/B978-0-08-0970868.53072-4.

Bucholtz, Mary \& Kira Hall (2003). Language and identity. In Duranti, A. (ed.) A Companion to Linguistic Anthropology. Oxford: Blackwell, 368-94.

Bucholtz, Mary \& Kira Hall (2005). Identity and interaction: A sociocultural linguistic approach. Discourse Studies, 7, 584-614.

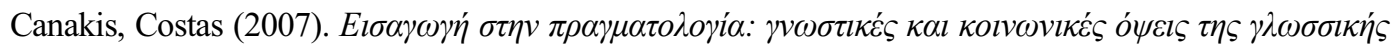

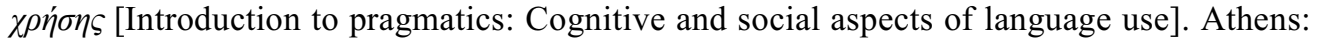
Ekdoseis tou Eikostou Protou.

Culpeper, Jonathan (1996). Towards an anatomy of impoliteness. Journal of Pragmatics, 25, 349-367.

Culpeper, Jonathan (2011). Impoliteness: Using language to cause offence. Cambridge: Cambridge University Press.

Davies, Bethan L., Andrew J. Merrison \& Michael Haugh (2013). Epilogue. In Davies, B.L., M. Haugh, \& A.J. Merrison (eds.) Situated Politeness. London: Continuum, 270-277. 
De Fina, Anna, Deborah Schiffrin \& Michael Bamberg (eds.) (2006). Discourse and identity. Cambridge: Cambridge University Press.

Dynel, Marta (2015). The landscape of impoliteness research. Journal of Politeness Research, 11 (2), $329-354$.

Eelen, Gino (2001). A critique of politeness theories. Manchester: St. Jerome.

Eller, Monika (2017). Reader response in the digital age: Letters to the editor vs. below-the-line comments: A synchronic comparison. Unpublished Ph.D. dissertation, Ruprecht-KarlsUniversität Heidelberg. https://archiv.ub.uni-heidelberg.de/volltextserver/23857/.

Fukushima, Saeko \& Maria Sifianou (2017) Conceptualizing politeness in Japanese and Greek. Intercultural Pragmatics, 14 (4), 525-555. https://doi.org/10.1515/ip-2017-0024.

Fyfe, Nicholas, Jon Bannister \& Ade Kearns (2006). (In)civility and the city. Urban Studies, $43(5 / 6), 853-861$.

Garcés-Conejos Blitvich, Pilar (2013). Introduction: Face, identity and im/politeness: Looking backward, moving forward: From Goffman to Practice Theory. Journal of Politeness Research, $9(1), 1-33$.

Garcés-Conejos Blitvich, Pilar \& Maria Sifianou (2017). Im/politeness and identity. In Culpeper, J., M. Haugh \& D. Kádár (eds.) The Palgrave Handbook of Linguistic (Im)Politeness. Basingstoke: Palgrave MacMillan, 227-256.

Georgalou, Mariza (2017). Discourse and identity on Facebook. London: Bloomsbury.

Grainger, Karen \& Sara Mills (2016). Directness and indirectness across cultures. Basingstoke: Palgrave Macmillan.

Hall, Stuart \& Paul Du Gay (eds.) (1996). Questions of cultural identity. London: Sage.

Halliday, M.A.K. (1985) An introduction to Functional Grammar (1st ed.). London: Edward Arnold.

Hardaker, Claire (2010). Trolling in asynchronous computer-mediated communication: From user discussions to academic definitions. Journal of Politeness Research, 6, 215-242. doi: 10.1515/JPLR.2010.011.

Hardaker, Claire \& Mark McGlashan (2016). "Real men don't hate women": Twitter rape threats and group identity. Journal of Pragmatics, 91, 80-93.

Haugh, Michael (2007). Emic conceptualisations of (im)politeness and face in Japanese: Implications for the discursive negotiation of second language learner identities. Journal of Pragmatics, 39, $657-680$.

Haugh, Michael (2010). When is an email really offensive? Argumentativity and variability in evaluations of impoliteness. Journal of Politeness Research, 6 (1), 7-31.

Haugh, Michael (2012). Epilogue: The first-second order distinction in face and politeness research. Journal of Politeness Research, 8 (1), 111-134.

Haugh, Michael \& Jonathan Culpeper (2018). Integrative pragmatics and (im)politeness theory. In Ilie, C. \& N. Norrick (eds.) Pragmatics and its Interfaces. Amsterdam/Philadelphia: John Benjamins, 213-239.

Howard, Judith A. (2000). Social psychology of identities. Annu. Rev. Sociol., 26, 367-393.

Jaworski, Adam, Nikolas Coupland \& Dariusz Galasiński (2004) Metalanguage: Why now? In Jaworski, A., N. Coupland \& D. Galasiński (eds.) Metalanguage: Social and Ideological Perspectives. Berlin \& New York: Mouton de Gruyter, 3-8.

Johnstone, Barbara (2008). Discourse analysis (2nd ed.). Oxford: Blackwell.

Joseph, John E. (2004) Language and identity: National, ethnic, religious. New York, NY: Palgrave Macmillan. 
Kádár, Dániel Z. \& Michael Haugh (2013). Understanding politeness. Cambridge: Cambridge University Press.

Kienpointner, Manfred (1997). Varieties of rudeness: Types and functions of impolite utterances. Functions of Language, 4 (2), 251-87.

Kienpointner, Manfred (2018). Impoliteness online: Hate speech in online interactions. Internet Pragmatics, 1 (2), 329-351.

Kristiansen, Tore (2003). The youth and the gatekeepers. Reproduction and change in language norm and variation. In Androutsopoulos, J. \& A. Georgakopoulou (eds) The Discursive Construction of Youth Identities. Amsterdam/Philadelphia: John Benjamins, 279-302.

Lakoff, Robin (2005). Civility and its discontents: Or getting in your face. In Lakoff, R.T. \& S. Ide (eds.) Broadening the Horizon of Linguistic Politeness. Amsterdam/Philadelphia: John Benjamins, $23-43$.

Locher, Miriam A. (2008). Relational work, politeness and identity construction. In Antos, G., E. Ventola \& T. Weber (eds.) Handbooks of Applied Linguistics. Volume 2: Interpersonal Communication. Berlin / New York: Mouton de Gruyter, 509—540. doi: 10.1515/9783110211399.4.509.

Locher, Miriam A. (2013) Situated impoliteness: The interface between relational work and identity construction. In Haugh, M., B.L. Davies \& A.J. Merrison (eds.) Situated Politeness. London: Bloomsbury, 187-208.

Locher, Miriam A. \& Brook Bolander, (2017). Facework and identity. In Hoffmann, C.R. \& W. Bublitz (eds.) Pragmatics of Social Media. Berlin/Boston: De Gruyter Mouton, 407-434. doi: 10.1515/9783110431070-015.

Locher, Miriam A. \& Brook Bolander. (2019). Ethics in pragmatics. Journal of Pragmatics, 145, $83-90$.

Locher, Miriam A. \& Martin Luginbühl (2019). Meta-discussions on Swiss and German politeness in online sources. In Ogiermann, E. \& P. Garcés-Conejos Blitvich (eds.) From Speech Acts to Lay Understandings of Politeness: Multilingual and Multicultural Perspectives. Cambridge: Cambridge University Press, 250-279.

Locher, Miriam A. \& Richard J. Watts (2005). Politeness theory and relational work. Journal of Politeness Research, 1 (1), 9-33.

Lodewijkx, Hein F.M. (2008). Reciprocity, norm of. International Encyclopedia of the Social Sciences (2nd ed.), 107-109.

Lorenzo-Dus, Nuria, Pilar Garcés-Conejos Blitvich \& Patricia Bou-Franch (2011). On-line polylogues and impoliteness: The case of postings sent in response to the Obama Reggaeton YouTube video. Journal of Pragmatics, 43 (10), 2578-2593.

Luzón, María-José (2018). Constructing academic identities online: Identity performance in research group blogs written by multilingual scholars. Journal of English for Academic Purposes, 33, 24-39.

Marwick, Alice (2013). Online identity. In Hartley, J., J. Burgess \& A. Bruns (eds.) Companion to New Media Dynamics. Malden MA: Blackwell, 355-364.

Mills, Sara (2003). Gender and politeness. Cambridge: Cambridge University Press.

Mills, Sara (2009). Impoliteness in a cultural context. Journal of Pragmatics, 41, 1047-1060.

Mills, Sara (2017). English politeness and class. Cambridge: Cambridge University Press.

Mills, Sara \& Dániel Z. Kádár (2011). Culture and politeness. In Kádár, D.Z. and S. Mills (eds.) Politeness in East Asia. Cambridge: Cambridge University Press, 21- 44.

Moser, Gabriel \& Denis Corroyer (2001). Politeness in the urban environment: Is city life still synonymous with civility? Environment and Behavior, 33 (5), $611-625$. 
Mouffe, Chantal (2005). For an agonistic public sphere. In Tønder, L. \& L. Thomassen (eds.) Radical Democracy: Politics between Abundance and Lack. Manchester, UK: Manchester University Press, $123-132$.

Mutz, Diana C. (2015). In-your-face politics: The consequences of uncivil media. Princeton NJ: Princeton University Press.

Mutz, Diana C. \& Byron Reeves (2005). The new videomalaise: Effects of televised incivility on political trust. American Political Science Review, 99 (1), 1-15.

Neurauter-Kessels, Manuela (2011). Im/polite reader responses on British online news sites. Journal of Politeness Research, 7, 187-214.

Niedzielski, Nancy A. \& Dennis R. Preston (2003). Folk linguistics. Berlin/New York: Mouton de Gruyter.

O'Driscoll, Jim (2013). Situational transformations: The offensive-izing of an email message and the public-ization of offensiveness. Pragmatics and Society, 4 (3), 369-387.

Ogiermann, Eva \& Vasiliki Saloustrou (2019). Conceptualising im/politeness in Greece and Great Britain. Paper presented at the 12th international conference on (im)politeness. Cambridge, 17-19 July 2019.

Ohashi, Jun \& Chang, Wei-Lin, Melody (2017). (Im)politeness and relationality. In Culpeper, J., M. Haugh \& D. Kádár (eds.) Handbook of Linguistic (Im)Politeness. Basingstoke. Palgrave MacMillan, 257-281.

Oz, Mustafa, Pei Zheng \& Gina Masullo Chen (2017). Twitter versus Facebook: Comparing incivility, impoliteness, and deliberative attributes. New Media \& Society, 20 (9), 3400 - 3419.

Papacharissi, Zizi (2004). Democracy online: Civility, politeness, and the democratic potential of online political discussion groups. New Media \& Society, 6 (2), 259-283. https://doi.org/ $10.1177 / 1461444804041444$.

Pavlidou, Theodossia-Soula (2014). Constructing collectivity with 'we': An introduction. In Pavlidou, Th.-S. (ed.) Constructing Collectivity: 'We' across Languages and Contexts. Amsterdam/ Philadelphia: John Benjamins, 1-19.

Perugini, Marco \& Marcello Gallucci (2001). Individual differences and social norms: The distinction between reciprocators and prosocials. European Journal of Personality, 15, 19-35.

Pinto, Derrin (2011). Are Americans insincere? Interactional style and politeness in everyday America. Journal of Politeness Research, 7 (2), 215-238.

Preston, Dennis (2005). What is folk linguistics? Why should you care? Lingua Posnaniensis, 47, $143-162$.

Reader, Bill (2012). Free press vs. free speech? The rhetoric of "civility" in regard to anonymous online comments. Journalism \& Mass Communication Quarterly, 89 (3), 495-513.

Rowe, Ian (2015) Civility 2.0: A comparative analysis of incivility in online political discussion. Information, Communication \& Society, 18 (2), 121-138. doi: 10.1080/1369118X.2014.940365.

Santana, Arthur D. (2014). Virtuous or vitriolic: The effect of anonymity on civility in online newspaper reader comment boards. Journalism Practice, 8 (1), 18-33. https://doi.org/ 10.1080/17512786.2013.813194.

Scott, Craig R. (2004). Benefits and drawbacks of anonymous online communication: Legal challenges and communicative recommendations. Free Speech Yearbook, 41 (1), 127-141. doi: 10.1080/08997225.2004.10556309.

Sellers, Mortimer (2003). Ideals of public discourse. https://papers.ssrn.com/sol3/papers.cfm?abstract_id= 1144719. (Last accessed, 16 September 2018). 
Sifianou, Maria (2019). Im/politeness and in/civility: A neglected relationship? Journal of Pragmatics, $147,49-64$.

Sifianou, Maria \& Angeliki Tzanne (2010). Conceptualizations of politeness and impoliteness in Greek. Intercultural Pragmatics, 7 (4), 661-687.

Smith, Philip, Timothy L. Phillips \& Ryan D. King (2010) Incivility: The rude stranger in everyday life. Cambridge: Cambridge University Press.

Spencer-Oatey, Helen (2002). Managing rapport in talk: Using rapport sensitive incidents to explore the motivational concerns underlying the management of relations. Journal of Pragmatics, $34(5), 529-45$.

Stryker, Robin, Bethany Anne Conway \& Taylor J. Danielson (2016). What is political incivility? Communication Monographs, 83 (40), 535-556. doi: 10.1080/03637751.2016.1201207.

Temmerman, Martina (2014). "Nail polish - We've chosen the nicest shades for you!": Editorial voice and 'we' in a Flemish women's magazine. In Pavlidou, Th.-S. (ed.) Constructing Collectivity. 'We' across Languages and Contexts. Amsterdam/Philadelphia: John Benjamins, 247-263.

Terkourafi, Marina (2011). From politeness1 to politeness2: Tracking norms of im/politeness across time and space. Journal of Politeness Research, 7 (2), 159-185.

Terkourafi, Marina, Lydia Catedral, Iftikhar Haider, Farzad Karimzad, Jeriel Melgares, Cristina Mostacero-Pinilla, Julie Nelson \& Benjamin Weissman (2018). Uncivil Twitter: A sociopragmatic analysis. Journal of Language Aggression and Conflict, 6 (1), 26-57.

Thurlow, Crispin, Lara Lengel \& Alice Tomic (2004). Computer-mediated communication: Social interaction and the Internet. London: Sage.

Tzanne, Angeliki (2019). Politeness, praising, and identity construction in a Greek food blog. Ogiermann, E. \& P. Garcés-Conejos Blitvich (eds.) From Speech Acts to Lay Understandings of Politeness: Multilingual and Multicultural Perspectives. Cambridge: Cambridge University Press, $48-67$.

Upadhyay, Shiv R. (2010). Identity and impoliteness in computer-mediated reader responses. Journal of Politeness Research, 6, 105-127.

van Dijk, Teun A. (1998). Ideology: A multidisciplinary approach. London: Sage.

van Dijk, Teun A. (2006a). Ideology and discourse analysis. Journal of Political Ideologies, 11 (2), $115-140$.

van Dijk, Teun A. (2006b). Politics, ideology and discourse. In Wodak, R. (ed.) Encyclopedia of Language and Linguistics, Volume on Politics and Language. Amsterdam: Elsevier, 728-740.

Verschueren, Jef (2012). Ideology in language use: Pragmatic guidelines for empirical research. Cambridge: Cambridge University Press.

Watson, Tony J. (2008). Managing identity: Identity work, personal predicaments and structural circumstances. Organization, 15 (1), 121-143.

Watts, Richard J. (1989). Relevance and relational work: Linguistic politeness as politic behaviour. Multilingua, 8, 131-166.

Watts, Richard J. (2003). Politeness. Cambridge: Cambridge University Press.

Watts, Richard J., Sachiko Ide \& Konrad Ehlich (1992). Politeness in language: Studies in its history, theory, and practice. Berlin: Mouton de Gruyter.

Wieland, Stacey M.B. (2010). Ideal selves as resources for the situated practice of identity management. Communication Quarterly, 24 (4), 503-528.

Zappavigna, Michele (2012). Discourse of Twitter and social media: How we use language to create affiliation on the web. London: Continuum International. 


\section{Article history:}

Received: 14 May 2019

Revised: 16 July 2019

Accepted: 11 October 2019

\section{История статьи:}

Дата поступления в редакцию: 14 мая 2019

Дата принятия к печати: 11 октября 2019

\section{Bionotes:}

MARIA SIFIANOU is Professor Emerita at the Department of English Language and Literature, National and Kapodistrian University of Athens. Her main research interests include im/politeness phenomena and discourse analysis. Her publications include Politeness Phenomena in England and Greece (Clarendon Press, 1992/1999/2002), Discourse Analysis (Hillside Press, 2006) and a number of articles in edited books and journals. She has co-edited Themes in Greek Linguistics (Benjamins, 1994) and Linguistic Politeness across Boundaries: The Case of Greek and Turkish (Benjamins, 2001) among others. She is on the editorial board of various journals and co-editor-in-chief of the Journal of Language Aggression and Conflict (Benjamins).

Contact information: msifian@enl.uoa.gr

ANGELIKI TZANNE is Associate Professor in Linguistics at the Department of English Language and Literature, National and Kapodistrian University of Athens. Since 1999 she has been teaching on the undergraduate and postgraduate programmes of the Department. Her research interests include sociolinguistics, pragmatics and discourse analysis, with particular emphasis on academic and media discourse. She has reviewed manuscripts for international linguistics journals and has also been on the editorial board of Pragmatics for several years. She is the author of a book (Talking at Cross-Purposes, 2000, Benjamins) and of a number of articles which have appeared in international journals and edited volumes.

Contact information: atzanne@enl.uoa.gr

\section{Сведения об авторах:}

МАРИЯ СИФИАНУ - почетный профессор факультета английского языка и литературы Афинского национального университета им. Каподистрии. Ее основные исследовательские интересы включают категорию вежливости и дискурс-анализ. Среди ее многочисленных публикаций - монографии Politeness Phenomena in England and Greece (Clarendon Press, 1992/1999/2002), Discourse Analysis (Hillside Press, 2006), ряд статей в рецензируемых сборниках и журналах. Она была соредактором сборников Themes in Greek Linguistics (Benjamins, 1994), Linguistic Politeness across Boundaries: The Case of Greek and Turkish (Benjamins, 2001) и др. Является членом редколлегий ряда журналов и соредактором журнала Journal of Language Aggression and Conflict (Benjamins).

Контактная информация: msifian@enl.uoa.gr

АНГЕЛИКИ ЦАННЕ - доцент кафедры лингвистики факультета английского языка и литературы Афинского национального университета им. Каподистрии. Ее исследовательские интересы включают социолингвистику, прагматику и анализ дискурса с особым упором на академический и медийный дискурс. Она является членом редколлегии журнала Pragmatics и рецензентом многих международных лингвистических журналов. Среди ее публикаций монография Talking at Cross-Purposes (Benjamins 2000) и ряд статей, опубликованных в рецензируемых международных журналах и сборниках.

Контактная информация: atzanne@enl.uoa.gr 